\title{
INTER-INSTITUTIONAL SOCIAL PARTNERSHIPS BETWEEN THE STATE AND THE CHURCH IN ROMANIA (WITH REFERENCE TO THE CHILD PROTECTION)
}

\section{Ion PETRICĂ}

University "Eftimie Murgu” of Resiţa, Romania

(C) 2015 Ion Petrică

This is an open access article distributed under the Creative Commons Attribution-NonCommercial-NoDerivs license

(http://creativecommons.org/licenses/by-nc-nd/3.0/)

DOI: $10.1515 /$ eras-2015-0002

\begin{abstract}
Compared to the European countries, the sociologic research related to religiousness and religious affiliation ranks Romania among the most religious countries, this aspect being proved also by the active positioning of the Church in society, especially in the public space. The verification of the phenomenon may be done also through our research theme, which has a content focused on social work, whose result may be used accordingly. There are publications in the field of social work also containing chapters about the Church as an institution, describing the specific activities with social character (either of philanthropy, or of empirical assistance, or even professionalised social work). Nevertheless, most papers mention the Church only in the description of some historical aspects of social work in Romania. Our topic is new because a research similar to ours has not been conducted in Romania yet, in our opinion, as in all bibliographic sources used in the writing of our paper he have found no research approaching such topics. The entire scientific endeavour starts from the formal systematic and non-systematic collaboration already existing between Churches and DGASPCs, but in order to scientifically validate this hypothesis we chose to conduct also a quantitative analysis of the data collected through a questionnaire with closed questions. The main purpose of our paper is the highlighting of the specificity of the interaction between the Church and the social work practice in Romania, through the existing partnership links between the State and the Church.
\end{abstract}

Keywords: child protection, State, social partnership, Church, social work

\section{Introduction}

In the past decades, one of the most debated phenomena has been globalisation (mondialisation). The desire to create the "global society" is expressed by most scientists, politicians, technocrats etc. On the contrary, those who are against it are the representatives of some cults and even thinkers who consider that globalisation is an artificial mechanism, which reflects a beautiful image of those who regard it, but which, inside it, develops trans-national interests of the great powers, who live with the idea and the desire to create a world's superpower chain.

The interest for globalisation is a new context for a new connection between economic and political stakeholders in the entire world. Globalisation was made possible by the gradual fall of commercial barriers and mobility of capitals, along with the technological progress and with the constant drop of the costs for transport, communication and informatics. "Its integrating logic seems inexorable, its boost irresistible. The benefits of globalisation are obvious: accelerated economic growth, higher living standards, acceleration of innovation, spread of technologies and managerial knowledge; new economic possibilities for individuals and countries alike." (Andria, 2007, p. 37).

Globalisation may be regarded through the prism of three great dimensions: the political, the economic and the social-cultural dimension. The connection between culture, economy and politics as regards globalisation is definitely a fact. "It is incorrect to make the categorical distinction between cultural and institutional processes as long as they represent simultaneous 
aspects of the global that are completely interconnected. The representation of other places, of other scenes, travels through the world are incorporated in institutions and organisations from the industry of tourism, and motivated by the very tourism. The mercantilist representations satiate both the practice and the company's individual interpretation." (Friedman, 2000, p. 202).

We must admit, if we are serious in highlighting the social stratification that the social work has, by excellency, a rather powerful connection with the entire landscape of international life. Depending on the manner in which society develops, the way in which the economic policies adopted in the world may eradicate or even cover poverty, we may speak about social policies meant to protect individuals, groups and even certain poorly-developed societies as regards the minimum subsistence needs. Although the literature says that the main goal of social policies is represented by the achievement of welfare, if we regard very carefully, at least in Romania we do not think that social policies have welfare as the main goal (especially personal wellbeing), but rather the providing of a support (financial., social etc.) to those in need.

The process of Europeanisation was defined from different perspectives as "adaptation of national policies to the EU political and economic dynamics", "a process by which domestic policies gradually become subject of the manner of elaborating the EU policies" or "the emergence and development of governance structures on the European level". "For Romania the process of Europeanisation seemed rather difficult. Europeanisation should have been the adoption and coming into force of the very European values that the Romanians lack, without these values we are savages in the eyes of the Western Europe's inhabitants. This lack is manifested on two planes: legal and behavioural. From the legal viewpoint, the Romanians' Europeanisation should bring to the "Mioritza's realm" clear and efficient laws, prompt and unbiased punishment of the guilty. On the other plane, of behaviour, many Romanians proved to be even further apart from European values. They still blindly follow the dicton "whatever, it may work just as well ", they are still not kind enough to the others and do not admit their own mistakes at all." (Nicolae, 2006). Legality and respect for the others and their values represent extremely important things for a healthy society with less social problems, who can aim at nothing else but welfare and obviously not at social degradation.

In the Eastern-European space, where the former Communist block crumbled down in 1989, these realities (legality and respect for the others) of a healthy community life would have had an empirical character, because religion itself promotes them, as all the states in the Eastern Europe are anchored in religion, which plays a rather important part in society.

As regards a research related to the Europeans' faith in a divine existence, the opinion poll conducted in the European Union's countries by the 2005 Eurobarometer found that on the average, $52 \%$ of the EU member states citizens claim they believe in God, $27 \%$ believe that there is a sort of divine spirit or life force, whereas $18 \%$ do not believe in the existence of any Spirit, God or Life Force, and 3\% refused to answer. "In order to describe the European confessional big picture, we may affirm on the EU territory there are that at present 6 great religious communities: Catholic, Protestant, Orthodox, Anglican, Muslim and Judaic. These were in 2001 in a European Union with 15 members (377 millions) distributed as follows: 51\% Catholics, 16\% Protestants, 6\% Anglicans, 3\% Orthodox, 3\% Muslims, 0.5\% Jewish and 20.5\% without a declared faith. In 2004, along with the adhesion of the ten new member states, the number of European citizens increased to 452 million, whereas the confessional representation is the following: 55\% Catholics, $15 \%$ Protestants, 5\% Anglicans, 3\% Orthodox, $2.5 \%$ Muslims, $0.5 \%$ Jewish and $19 \%$ without a declared confession." (Carp, 2007, p. 298). As we may see, the proportion of the Catholics increased, due especially to Poland's joining, valid for 2004. Once Romania and Bulgaria joined the Union in 2007, the proportion of the Orthodox definitely grew because Romania is a country with $87 \%$ declared Orthodox believers, according to the 2002 census, and Bulgaria with the percentage of $85 \%$ persons who declared to be Orthodox.

Beside Europeanisation, a much more acceptable process, we may say, we are witnessing the other process taking place in the world, which is rather appreciated by some, and vehemently challenged by others: globalisation. Globalisation represents a historic and irreversible process of social development, determined by a multitude of factors like technology, market economy, liberalisation. "Undoubtedly the phenomenon of liberalisation, by its modern forms of manifestations, directly influence the systems of social work and assistance: modern management and infrastructure, global communication network, high-performance human 
capital and expertise, new social problems and implicitly new categories of beneficiaries." (Buzducea, 2009, p. 29).

\section{Confluence between religiousness and contemporary social work and assistance}

"Religion and science have shared a long history of antagonism, scepticism and mutual concessions. Many a time this history was the expression of the relation between the Church and the State or of the conflict between the religious and the secular individual. During most of the 20th century the interest for psycho-biologic researches, pragmatism, behaviourism or experimentalism pushed these fields of science into a totally refractory position towards religion."(Vraşti, 2006). According to Freud (1953) the religious person is a neurotic person with obsessive-compulsive traits. Ellis (1980) considered religion as the institutionalisation of irrationality, being inflexible and intolerant, definitely ignoring the irrationality described by R. Otto (1992). Nevertheless, there were authors who saw religion as a source of comprehension and stability in an uncertain world (Jung, 1933; Allport, 1950).

As for the religiosity aspects in the paper The Religious Factor (1961), Gerhard Lenski analyses the difference in orientation toward the economic and political issues, highlighting the difference between Jews, Protestants and Catholics, partially considering an influential typology of the dimensions of "religiosity" - which he identifies as dogmatics or faith, association (or number of believers), devotion (related to aspects such as prayer) and communality (degree of segregation of the religious group).

For A. Giddens (2000) one of the dimensions of laicisation refers to beliefs and values. He tells us we may call this dimension religiosity. Obviously, the extent to which people go to church and the degree of social influence are not predilecting, a direct expression of preserving faiths and ideals. Many people with religious beliefs do not regularly attend mass or public ceremonies, the habits to attend not always implies the existence of strong religious convictions - people may go to church out of habit or because they are expected to within the community. Although people were caught in the influence of profanity, many express their faith in a certain force, divinity etc., even if they fail to totally define them.

The past decades have brought about a change of general attitudes towards religion and more and more people declare to be "religious". A Gallup survey (1999) show that $95 \%$ of the Americans declare to believe in God and $42 \%$ regularly go to church. In all cultural spaces the interest for religion in general is increasing and the affiliation to a religion started to be declared as an important part of individual and national identity. These aspects are only related to America, we shall see in our research the standpoint - for instance - of Eastern Europe from the perspective of religiousness. In Romania too, although it experienced the Communist period for almost half of a century, after 1990 the sociologic researches related to religiosity show a significant growth.

Giddens disagrees when it comes to religiousness and people's increasing interest for religion and religious affiliation. He said that "The influence of religion has decreased in each of the three dimensions of laicisation. Should we conclude that the 19th century authors were in fact right? Probably the fall of religion lasted longer than they had anticipated? Such conclusions could be debatable. The call of religion, both in its traditional and its new forms, is likely to be still lasting. The modern rationalist thinking and the religious perspective coexist in an uncomfortable state. A rationalist perspective conquered many aspects of our existence, and its power is not likely to relent in the near future. However, there will definitely be reactions against rationalism that will lead to periods of religious rebirth. There are probably few people in the world who had never been touched by religious feelings, and science and rationalist thinking cannot answer fundamental questions such as the purpose of life in general - issues that have always been within religion." (Giddens, 2000, p. 502).

Schwartz and Huismans (1995) say that religion offers a basis for understating why some norms and social structures are prevailing in a culture, it leads to the acceptation of social order and discourages innovations and its questioning and debate. Inglehart (2000) also thinks that the dominant religion in each society is related to the types of values considered to be the most important for it. "Thus, the Protestant European countries grant a higher importance both to individual expression and to secular-rational values, whereas Catholic European countries 
assign a lower importance to both types of values. When they study the relations between religion and values, the two authors find the following correlations:

1. a positive relation between religiosity and conservatism, because reservation, order and resistance to change are compatible with religiosity to the highest degree;

2. a negative correlation between religiousness and its openness to change, hedonism in particular being the most incompatible with religious ideas;

3. a positive relation between religiosity and transcendence because generosity and perception of the fellow humans' interest are essential components of the doctrinal core of religions."(Vraşti, 2006).

Giddens, Gallup, Schwartz and Huismans forward opinions in accordance with sociologic research conducted in relation with religiosit, and on the other hand one witnesses a rebirth of the religious on the individual level, which, in fact, means a religious influence (of religiosity) on the level of society.

\section{The early connection between State and Church in relation with social work in Romania}

A highly debated and sensitive relation for the European Union and for the entire world is that of the connection between Church and State. The de-Christianisation process (Baechler, 2006) of Europe started a long time ago, even in the Enlightenment period, if not even earlier for some peoples, and brought about secularisation in many of the world's states. Thus, must of the states, sooner or later, were totally detached from the influences or even symbiotic links with the Church they used to display in the periods prior to the birth of Enlightenment (period of the 17th - 19th centuries). August Comte, the father of the term of "sociology" (Johnson, 2007 , p. 328) claimed that the only and highest form of knowledge is the description of sensorial phenomena. "Comte claimed that there are three stages of human faith: the theological, the metaphysic and the positive, called thus because they are limited to only what is positively given, avoiding any speculation." (Blackburn, 1999, p. 311). On the ground of such a statement, the European states, especially the western ones, have gradually escaped the doctrinal Christian influences and aligned to other trends, of rather political nature, where we will witness later on the separation of the laic power from any religious form or any metaphysical influence.

In Romania the State-Church relation is very good. As regards social work, we may speak even of an interconnection. The representatives of the Church are present in the children's placement centres and in almost all institutions of social protection, irrespective of field: either the protection of the child, or the gerontology social assistance etc. We could easily see the relation between state and church in Romania even from the start, since the foundation of Romanian states (cf. Petrică, 2012, p. 35). In the History of Romanians we read the following: "According to the Byzantium model, the ruler of "TTara Romînească" (Wallachia) was the representative of divinity, God's anointed on earth. By the creation of the Wallachia Metropolitan Bishopry or Episcopate, he consolidated his throne and position, becoming, like the Byzantium emperor, both civil and religious monarch. The fact to be "anointed" conferred the monarch, as well as the Metropolitan Bishop, the sacerdotal prerogatives. The ruler was "anointed" by the Metropolitan Bishop, but the latter in his turn had to be recognised as shepherd and guide of the believers by the ruler." (History of Romanians, 2001, p. 250).

In the Romanian space, "in the 18th century one organised, beside diverse monasteries, the so-called "bolniţe" (houses for the sick), that were in fact asylums for the poor sick people, for invalids and in general for the old poor. The terms we encounter, designing the assisted, were of "missel" for those who presented bodily infirmities and of "nemernici" for socially challenged people: beggars and vagabonds." (Mănoiu, Epureanu 1996, p. 4). After wars, the rulers or some boyars erected churches or monasteries in order to thank God for their success against the enemies of the country. Next to these sacred locations "bolniţe" or asylums for the poor sick, the infirm or the destiny-stricken were established.

In the traditional period, the social worker was in general a good Christian. All the time the efforts of the social worker, of the Christian who served the persons in need were directed towards certain interest, such as:

- Family assistance;

- Care for the poor; 
- Assistance for the orphans;

- Assistance fpr widows;

- Assistance of all persons or groups who suffered for calamities; (Stan, 2003).

The church will still remain with these preoccupations in a much more restrained form, because even the access to resources will be reduced along with the modernisation of European states and their separation from the Church, process started with the world's industrialisation, dating from the Enlightenment period, more precisely along with the social change produced by the 1789 French Revolution (cf. Petrică, 2010, pp. 39-40).

In today's Romania, as we previously mentioned, the State-Church relation is in general one of reciprocity. This aspect is also presented scientifically through the opinion polls, because traditional institutions, such as the church and the army, enjoy the highest trust. More than four Romanians out of five trust these institutions, with a slight increase of the confidence in church. "Given the characteristics of these institutions (strict hierarchy combined with the respect for order in the case of army and provider of the absolute truth in the case of the church), the excessive trust in them and the low confidence in more democratic institutions can be interpreted as a sign that the Romanians have no democratic culture yet. Although this may be true, the high trust in traditional institutions is not the appropriate indicator to reach this conclusion. Similar levels of trust in the church and army may be remarked also among the American citizens, for instance, that may be described in many ways, but not lacking democratic culture. In a modern society (we do not discuss here how modern the Romanian society is) the main function of two institutions is symbolic; their image in the collective mentality is that of protector of the ego (physical in the case of the army, and spiritual in the case of the church).“(Tufiş, 2007, p. 135).

Figure 1. Romanians' trust in traditional institutions

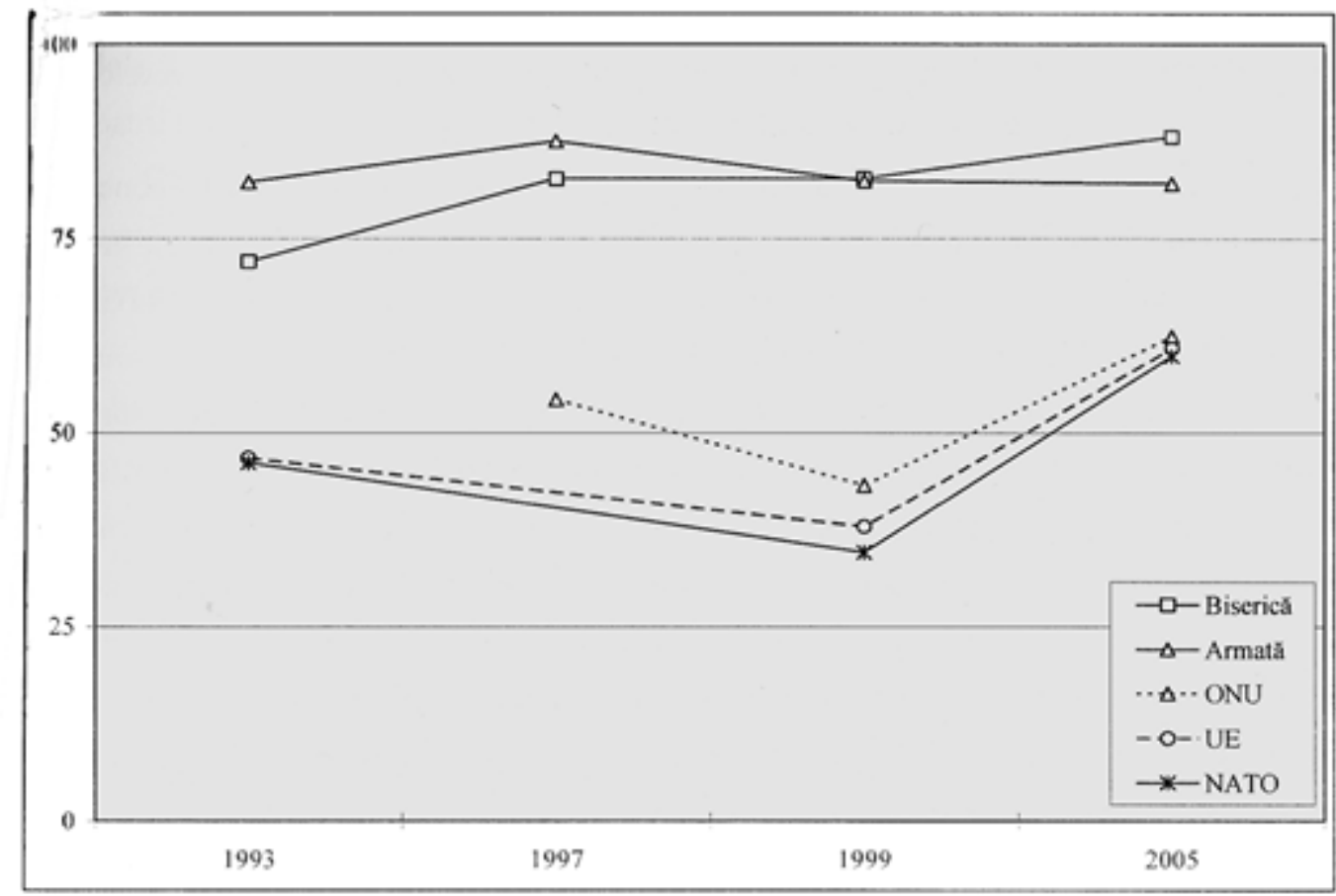

Source: Claudiu Tufiş, 2007, p. 135.

Immediately after 1990, as the army had played a special role in the 1989 events, it was the institution that offered Romanians the highest trust. Immediately after it came the Church. In the past years, rather suprinsingly, considering that Romania joined the NATO and then the EU, the Church's credibility has not only remained unchanged, but on the contrary, it has become the first institution of trust for the Romanians. "The church is the institution enjoying the highest confidence from the part of Romanians, together with the army. This is well known 
and demonstrated by all researches focused on the trust in institutions. Despite the scandals in which the members of the Romanian Orthodox Church have been involved since 1990, the institution is in the top of trust and it seems nothing can affect this position." (Voicu, 2007, p. 117). Several explanations have been attempted for this phenomenon, referring either to social needs, which could justify this capital of trust (Sandu, 1999), or to the fact that the Church capitalised the loss of social support by other political stakeholders much more involved in the process of economic and political change, such as the parliament or the government.

This trust granted to the Church in Romania makes its presence in the public space not diminished and then forbidden by legislation, as it happens in some European countrie. We may even say that its presence in the public space got amplified. We find priests employed by the Romanian state and developing a professional career of priest in institutions of health, military organisms, asylums and placement centres, in education etc. For example, the priests who are the employees of the Romanian state in these institutions setup small prayer locations such as chapels, oratories and even churches. Our research will be focused only on the presence of the Church through partnerships in state-funded social work institutions, and our interest will focus especially on a certain field of social work. In this respect we selected child protection, a domain where rather many reforms were done, being in fact a condition imposed by the European Union regarding Romania's adhesion to the great European family.

Unlike most countries in the region, Romania is the country where the religious values still exercise a significant influence on public and private life of people. "For the Romanians, a high level of religiousness may bring about not only the preference for a traditional family pattern, but also the orientation toward the rejection of democratic governance alternatives of a country, and also the stimulation of the motivation for work. According to the data collected, the Romanian believers are more motivated to work, irrespective if they go to work for the money or for personal development. We must mention still that it is possible that the stimulating effects of labour are due not only to religious faith, and it is possible that other intermediary factors could intervene between the two variables." (Voicu, 2007, p. 115).

\section{Child protection in Romania. The connection between State and Church on the partnership level}

The State-Church relations in Romania, as regards social work and assistance, leads us to the idea that there is diversity and complementarity between the traditional Christian altruism and the modern standards of laic social work. The church was even involved in a project of promoting the legislative package adopted in 2004 for to the promotion and protection of children's rights (Law no. 272 regarding the protection and promotion of chidlren's rights, Law no.273 regarding the legal regime of adoption, Law no.274 regarding the creation, organisation and operation of the Romanian Office for Adoption and Law no. 275 regarding the National Authority for the Protection of Children's Rights), laws that are now slightly modified, project in which priests were the targets groups. This brings about the comprehension that in Romania the professionalised social work needs also Christian assistance. Moreover, this aspect was underlined also in the manual edited by the National Authority for the Protection of Children's Rights (the name of the institution at that time), which reads: "Priests, as well as other professional categories who interact with children and their parents, can help parents develop a positive behaviour. They can offer guidance when parents cannot satisfy the basic needs of children and can guide parents towards the services / authorities that can help them. Furthermore, they may offer information about the negative effects of the physical punishment and about the alternative methods that can be used for the education of the child. Some of these methods are listed in the example below. When a priest offers such information, he should take into account the tone, the respect for the parents' dignity and their efforts to take care of the children. One of the most complex aspects is that of recommendations related to the growth of parental capacities, many parents manifesting reluctance to introduce changes in the way they relate to the child and to accept professionals' interventions. By its very vocation, the priest may find the most appropriate mode to communicate with the parents, showing comprehension for the situation of each family and adapting the message so that it could be accessible to each person to whom it is addressed." (The role of priests in the protection and promotion of children's rights, 2006, p. 33). 
In the Communist period, i.e. until 1990, the policy of children's protection in Romania had a categorically centralised character, favouring the chidlren's institutionalisation and less the responsibilisation of family and community, system specific to Communist ideology, when one believed that the system masters the social situation of the country and denied the existence of major social issues. That is why one arrived very easily at a rather serious situation regarding the institutionalised children, because, when Communism fell, the international press wrote and broadcast materials with the inhuman situation of the children in Romania's orphanages, because the system met only the strict minimum needs related to subsistence: food, clothing, superficial education etc.

After the ratification of the UN Convention regarding the Children's Rights, Romania pledged itself to promote the rights of the child in accordance with the principles and norms listed in the Convention. Unfortunately, in the period 1990-1996, one elaborated numerous normative acts (regarding adoption, court's ruling of child abandonment, special protection of handicapped persons etc.) that aimed at improving the child's protection frame, but without reconsidering it in its ensemble, which led to the preservation of the fragmentary and excessively etatised character, by the creation of new administrative structures in the field.

"The important year as regards child protection, as we mentioned in this paper in the theoretic section of our research, is 1997, when Romania's Government adopted the Emergency Ordinance no. 26/1997 regarding the protection of the child in difficulty, laying the bases of a new protection system. In the subordination of county councils and Bucharest City local councils, one will create organisms in charge with the establishment, application and monitoring of measures for the protection of the child in difficulty: The Commissions for Child Protection, conceived as specialised organisms of the local public administration; The public services specialised in child protection, public institutions intended as "executive bodies" of the commissions, with the mission of ensuring the protection of children in difficulty, the granting of assistance in realising and exercising their rights and supplying support to the family for the prevention of the situations endangering the child security and development." (Petrică, 2012, p. 174).

The General Direction is the public institution with legal personality, created in the subordination of the county councils and the local councils of the Bucharest City districts, by the merger of the public service of social assistance and the public service specialised in child protection on the level of the counties and of the Bucharest City districts, by the adequate taking over of their tasks and function. The General Direction provides, on the local level of the counties and of Bucharest City districts, the social asssitance actions in the field of child protection, family, single persons, senior citizens, handicapped persons, as well as of any other persons in need.

As regards children's protection, DGASPC fulfils the following attributions:

„1. It draws up the report of initial evaluation of children and their family and proposes the establishment of special protection measures;

2. It quarterly monitors the activities meant to implement the decisions taken for children's protection;

3. It identifies and evaluates families or persons that can take the child in placement;

4. It monitors the families and persons who were entrusted children in placement, during the entire period of this measure;

5. it identifies, assesses and prepares persons who may become professional maternal assistants (foster parents), in the conditions of the law; it concludes individual contracts and assures the continual training of attested maternal assistants; it evaluates and monitors their activity;

6. it grants assistance and support to the parents of the child separated from his family, in view of reinserting the child into his family environment;

7. it re-evaluates, at leas once in 3 months, and when the case may be, the circumstances at the basis of the establishment of the measures of special protection and proposes, according to the case, their maintenance, change or cease;

8. it fulfils the endeavours for opening the procedure of internal adoption of the children in its evidence; 
9. it identifies the families or persons with the domicile in Romania who desire to adopt children; it evaluates the material conditions and moral guarantees they present and issue the family certificate or the certificate of person apt to adopt children;

10. it monitors the assessments of the adopted children and the relations between them and their adoptive parents; it supports the chidlren's adoptive parents in fulfilling their obligation to inform the child he is adopted, as soon as the age and degree of maturity of the child allow it;

11. fulfils any other attributions stipulated by the law" (HG no. 1434/2004).

Once the county directions of child protection were founded, the need for professional social workers increased rather much. The profession of social worker has a recent history, despite the fact that the assistance services developed, under one form of another, as the human civilisation evolved. "The domain of social work and assistance was circumscribed as a clearly delimited profession only at the beginning of the 20th century, more precisely along with the first differences between diverse types of social services providing. In the literature we find mentions that until that moment today's role of social work was played by diverse charity associations, either co-ordinated by the Church, or had a private status. When the issue of social work or the social system stakeholders who were increasingly defavoured became extremely important on the agenda of the political leaders of the respective society, it was found that, only on the principle of charity actions, usually sporadic and often inefficient, it is not possible to keep a social balance. Hence the building of a system aiming at monitoring the improvement of the living conditions of all defavoured persons, supposing legislative measures, large-sclae material and human efforts "(Tompea, 2003, p. 417).

The birth of a system was needed in social work and assistance. Social workers need a strong legislative frame in order to carry on their activity, keeping in mind that their role is not only to help the client understand his right to self-determination, but also to assume his social responsibility. Self-determination is limited by social responsibility. The social worker must use his authority to help the client comprehend the consequences of behaviour. The social worker should also accept his responsibility as regards those who cannot protect themselves, i.e. victims of diverse categories of abuse.

Even if in Romania one created an interesting legislative frame meant to develop and reform the old system of child protection, the Church was, directly and indirectly, still comprised as a potential partner of the activity of social assistance in our country.

\section{Consistent formal collaboration between the county institutions of child protection (DGASPC) and the central units of cult (bishopries, archbishopries and metropolitan episcopates) on the level of the respective county (methodology, analysis and results)}

In view of conducting such a research we elaborated a questionnaire with closed questions. We monitored in the data collected from the application of this questionnaire the existing official relations on the level of the county between DGASPC and the institutional form of Church leadership in the respective county. We were interested first of all in the existence of partnerships or collaboration conventions either strictly between Bishopry / Archbishopry / Metropolitan episcopate and DGASPC, or those concluded between the two aforementioned institutions and other institutions involved in the fight against a certain phenomenon, such as the prevention and fight against child's labour exploitation etc. Furthermore, we were interested in the possible existence of simple corporations (of non-standardised collaboration), but also the total lack of co-operation between the two: Church and DGASPC.

We chose as working hypothesis: The mutual relations between Church and DGASPC are structured on consistent partnership patterns

The data received following our request from all 47 DGASPCs (41 county direction +6 directions in Bucharest City districts) were the following:

Table 1. Relation between DGASPC and the local Church 


\begin{tabular}{|c|c|c|c|c|}
\hline \multirow{2}{*}{ No. } & \multirow{2}{*}{$\begin{array}{l}\text { DGASPC of } \\
\text { county... }\end{array}$} & \multicolumn{3}{|c|}{ Relation between DGASPC and the local Church } \\
\hline & & Partnerships & Simple collaborations & No collaboration \\
\hline 1. & Alba & $\mathrm{x}$ & & \\
\hline 2. & Arad & $\mathrm{x}$ & & \\
\hline 3. & Argeş & & $\mathrm{x}$ & \\
\hline 4. & Bacău & $\mathrm{x}$ & & \\
\hline 5. & Bihor & & $\mathrm{x}$ & \\
\hline 6. & Bistriţa-Năsăud & & $\mathrm{x}$ & \\
\hline 7. & Botoşani & & $\mathrm{x}$ & \\
\hline 8. & Braşov & & $\mathrm{x}$ & \\
\hline 9. & Brăila & $\mathrm{x}$ & & \\
\hline 10. & Buzău & & $\mathrm{x}$ & \\
\hline 11. & Caraş-Severin & $\mathrm{x}$ & & \\
\hline 12. & Călăraşi & $\mathrm{x}$ & & \\
\hline 13. & Cluj & & $\mathrm{x}$ & \\
\hline 14. & Constanţa & $\mathrm{x}$ & & \\
\hline 15. & Covasna & & $\mathrm{x}$ & \\
\hline 16. & Dâmboviţa & $\mathrm{x}$ & & \\
\hline 17. & Dolj & $\mathrm{x}$ & & \\
\hline 18. & Galaţi & & $\mathrm{x}$ & \\
\hline 19. & Giurgiu & $\mathrm{x}$ & & \\
\hline 20. & Gorj & $\mathrm{x}$ & & \\
\hline 21. & Harghita & & $\mathrm{X}$ & \\
\hline 22. & Hunedoara & & $\mathrm{x}$ & \\
\hline 23. & Ialomiţa & & $\mathrm{x}$ & \\
\hline 24. & Iaşi & $\mathrm{x}$ & & \\
\hline 25. & Ilfov & & $\mathrm{x}$ & \\
\hline 26. & Maramureş & $\mathrm{x}$ & & \\
\hline 27. & Mehedinţi & $\mathrm{x}$ & & \\
\hline 28. & Mureş & $\mathrm{x}$ & & \\
\hline 29. & Neamţ & $\mathrm{x}$ & & \\
\hline 30. & Olt & $\mathrm{x}$ & & \\
\hline 31. & Prahova & $\mathrm{x}$ & & \\
\hline 32. & Satu Mare & & $\mathrm{x}$ & \\
\hline 33. & Sălaj & & $\mathrm{x}$ & \\
\hline 34. & Sector 1 & $\mathrm{x}$ & & \\
\hline 35. & Sector 2 & $\mathrm{x}$ & & \\
\hline 36. & Sector 3 & $\mathrm{x}$ & & \\
\hline 37. & Sector 4 & $\mathrm{x}$ & & \\
\hline 38. & Sector 5 & & $\mathrm{x}$ & \\
\hline 39. & Sector 6 & $\mathrm{x}$ & & \\
\hline 40. & Sibiu & $\mathrm{x}$ & & \\
\hline 41. & Suceava & $\mathrm{x}$ & & \\
\hline 42. & Teleorman & $\mathrm{x}$ & & \\
\hline 43. & Timiş & $\mathrm{x}$ & & \\
\hline 44. & Tulcea & & $\mathrm{x}$ & \\
\hline 45. & Vâlcea & & & $\mathrm{x}$ \\
\hline 46. & Vaslui & $\mathrm{x}$ & & \\
\hline 47. & Vrancea & $\mathrm{x}$ & & \\
\hline \multicolumn{2}{|c|}{ TOTAL } & 29 & 17 & 1 \\
\hline
\end{tabular}

As for the relation between DGASPCs with the local Church (meaning connection between DGASPC and parishes, deaneries, bishopries, archbishopries, metropolitan episcopates), we have the following values as results of our research: As for partnerships / collaboration convention, 29 DGASPCs have signed such official documents with the local Church, which represents a $62 \%$ percentage. In relation with simple collaboration (without drawing up official 
documents but mere bilateral agreements), 17 DGASPC institutions confirmed the collaboration with the Church, without having an official written support. As for the lack of collaboration, we find one single direction in this situation, that of Vâlcea county.

In order to scientifically test our Hypothesis we used certain instruments of interpretation of the relations between the local Church and DGASPC, as follows:

1. partnerships / conventions - formal systematic collaboration;

2. simple collaborations - formal non-systematic collaboration;

3. no collaboration - lack of collaboration.

Graph 1. Validation of the Hypothesis

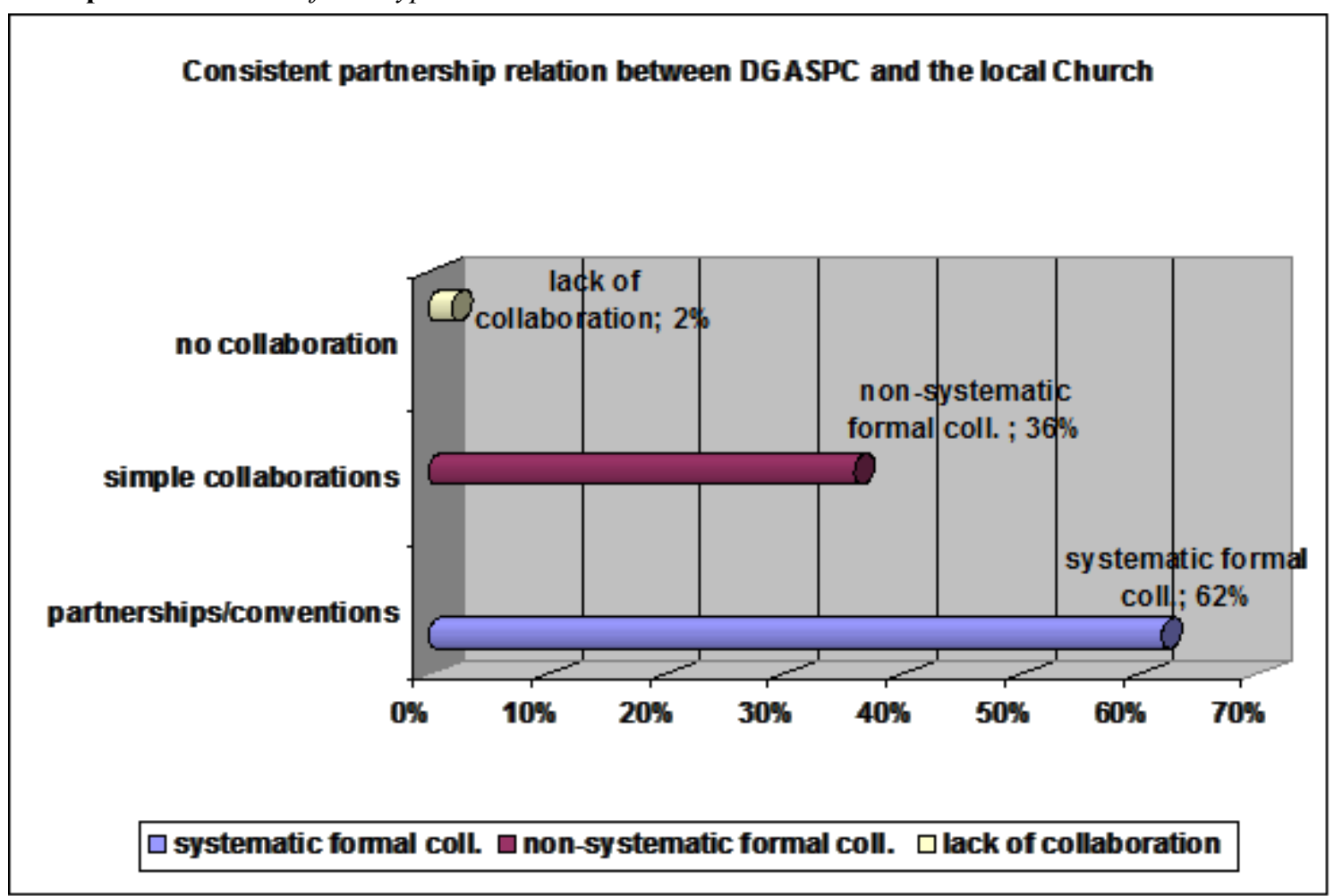

\section{Discussions}

Our hypothesis is scientifically validated through the graph plotted from the pervious geographic image. The relations of mutual collaborations between the DGASPC institution of the respective county and the local Church, in Romania, is structured on consistent partnership patterns. We find almost $2 / 3$ of the counties with systematic formal partnerships, and the rest with non-systematic collaboration, except Vâlcea county, where there is no form of collaboration between the precious two.

From our research and its results for Romania it follows that 25 years after the fall of Communism the Church and Romanian State carry on, each within its frame, an activity of social work and assistance on a professionalised level in accordance with the principles specific to each of them, but the relation between the two is complementary due to the existing partnership activities. Taking into the account the importance of the Church in the Romanian society, it is mentioned even on the legislative level related to the social work, the Church is present not only as aspect of formality in the public system of social work and assistance. It is present in all its spiritual means and in all fields of activity of social work: in institutions for the protection of children, senior citizens etc. 


\section{Conclusions}

The research conducted and the results for Romania show that after 20 years from the fall of Communism, the Church and the Romanian State carry on, each in its sectors, an activity of professionalised social work activity, but the relation between the two is complementary, the state often allotting resources to the Church for the activities with social character conducted by it, but taking into account also the importance of the Church in today's Romanian society. It is present with all its spiritual means and in all domains of activity of social work: in the institution for the protection of children, senior citizens etc. Compared with many states of the European Union, in Romania the relation between the Church and the State and regarding social work is one of collaboration by means of partnerships. What exists in Romania cannot even be conceived in other states, such as the creation of such a collaboration where, for instance, the social worker could be consecrated as spiritual leader and develop a professional career. The results of the research should not be interpreted as a return to the medieval lifestyle, where the Church was in "expansion" conquering everything, but we must comprehend that the Church, by its presence, contributes to the consolidation of the national system of social work. In this case we can no longer place the sign of equality between ecclesial social work and philanthropy, in the sense that in the Church there is only the form of mutual help, but we can even speak about the practising of professionalised social assistance and work.

Our scientific endeavour is not meant "to check" the idea that it is a good thing for the Church to remain involved in society as it is now. The sociologists who came very close to the field of sociology of religion (a field very intensely approached by sociologists in the last decades), have conflicting opinions. Most speak about a separation between religion and society, in exchange there are some who see a major importance in the religious revival of society. We are still to determine the manner in which society and individuals will remain in a secularising sprit or in a reviving spirit as regards religiousness.

\section{References}

Andria, A. (2007) Liberal democracy and globalisation. In Liberal democracy and globalisation, eds. Graham Watson and Katherine Durrant, 35-45, Bucharest: Ziua Editions.

Allport, G.W. (1950) The Individual and His Religion: A Psychobiological Interpretation. New York: Macmillan. Baechler, J. (2006) Religion. In Treaty of sociology, $2^{\text {nd }}$ edition, ed. Raymond Boudon, 501-545. Bucharest: Humanitas.

Blackburn, S. (1999) Dictionary of philosophy (Oxford). Bucharest: Univers Enciclopedic.

Buzducea, D. (2009) Modern systems of social assistance / Global trends and local practices. Iaşi: Polirom.

Carp, R. (2007). State, Church, citizens — in search of a European model of religions. In For a Christianity of new Europe, eds. Teodor Baconsky et al., 298-300, Bucharest: Humanitas.

Ellis, A. (1980) Psychotherapy and atheistic values, a response to A. E. Bergin's Psychotherapy and religious values, Journal of Consulting and Clinical Psychology, 48:635-639.

Friedman, J. (2000) Cultural identity and global process. London, Thousand Oaks, New Delhi: SAGE Publications.

Freud, S. (1953) The Future of an Illusion. New York: Liveright.

Giddens, A. (2000) Sociology. Bucharest: ALL.

Gallup, G. jr. \& Lindsay, D. M. (1999) Surveying the Religions Landscape: Trends in US Beliefs, Harrisburg PA: Morehouse.

Ingelhart, R. (2000) Culture and democracy. In Culture matters. Human values shape human progress, eds. Lawrence E. Harrison and Samuel P. Huntington, New York: Basic Books.

Johnson, G. A. (2007) Blackwell dictionary of sociology. Bucharest: Humanitas.

Jung, C. (1933) Modern Man in Search of a Soul. New York: Harcourt Brace Jovanovich.

Lenski, G. E. (1961) The religious factor; a sociological study of religion's impact on politics, economics, and family life. Garden City, N.Y.: Doubleday.

Mănoiu, F. \& Epureanu, V. (1996) Social work in Romania. Bucharest: ALL.

Nicolae, L. (2006) Romania's true Europeanisation, http://old.cotidianul.ro/editorial_ adevarata_europenizare_a_romaniei-17889.html

Otto, R. (1992) [1917] Das Heilige. Ueber das Irrationale in der Idee des Göttlichen und sein Verhälnis zum Rationalen, English translation: The sacred: on the irrational element in the idea of the divine and about its relation with the irrational, Cluj: Dacia. 
Petrică, I. (2010) Complementarity between the Church and the Romanian state regarding the child protection. Timişoara: Nepsis/Eurobit.

Petrică, I. (2012) The church and social work in Romania. Iaşi: The European Institute.

Sandu, D. (1999) The social space of transition. Iaşi: Polirom.

Schwartz, H. Salom and Huismans, Sander. 1995. Value priorities and religiosity in four Western religions. Social Psychology Quarterly 58: 88-107.

Tufiş, C. (2007) Institutional trust_-victim of post-Communist transition. In Values of Romanians, eds. Bogdan, Voicu \& Mălina, Voicu, 117-149. Iaşi: The European Institute.

Tompea, D. (2003) Ethics of social work and construction of the professional paradigm. In Treaty of social work, ed. George Neamţu, 401-464. Iaşi: Polirom.

Voicu, M. (2007). The religious Romania, Iaşi: The European Institute.

Vraşti, R. (2006). Relation between religiosity / spirituality and physical and mental health, http://www.vrasti.org/Relatia\%20dintre\%20religie $\% 20$ si $\% 20$ spiritualitate $\% 20$ si $\% 20$ sanatatea $\% 20$ fizica $\% 20$ si\%20cea\%20mentala.pdf

${ }^{* * *}$ The Romanian Academy. 2001. History of Romanians. vol. IV. Bucharest: The Enciclopedic Editions.

*** The National Authority for the Protection of Children's' Rights. 2006. Role of priests in the protection and promotion of children's rights. Bucharest: Trei.

*** Law no. 272/2004 regarding the protection and promotion of children's rights in Romania's Official Gazette, Part I no. 557 of $23^{\text {rd }}$ June 2004.

${ }^{* * *}$ Law no.273/2004 regarding the legal regime of adoption republished in 2009 The Law of Adoption in Romania's Official Gazette, Part I no. 788 of $19^{\text {th }}$ November 2009.

${ }^{* * *}$ Law no. 274/2004 regarding the creation, organisation and operation of the Romanian Office for Adoption and republished in 2010 in Romania's Official Gazette, Part I no. 108 of $17^{\text {th }}$ February 2010.

${ }^{* * *}$ Law no. 292/2011 regarding the national system of social work in Romania's Official Gazette no. 905 of $20^{\text {th }}$ December 2011.

${ }^{* * *}$ Law no. 275/2004 regarding the National Authority for the Protection of Children' Rights in Romania's Official Gazette no. 557 of $23^{\text {rd }}$ June 2004.

${ }^{* * *}$ Government Decision no. 1434/2004 regarding the attributions and Frame Regulation for the organisation and operation of the General Direction of Social Work and Child protection in Romania's Official Gazette no. $869 / 2004$. 